\title{
Flexural Behaviour of Reinforced Concrete Beam by using Steel Fibres \& Glass Fibres
}

\author{
R. Chitra, S. J. Mohan, S. Thendral, A.Arunya
}

\begin{abstract}
The work aims to compare the flexural behavior of concrete beam using addition of steel fibers and glass fibers with normal beam in M30 grade concrete and to find the cracks developed in the concrete beam. Experiments include Compression test, Tensile strength and Flexural strength. In this study the performance of fiber reinforced concrete (FRC) beams under two-point loading system is discussed and comparative studies were made with normal mix concrete. In this study, we are casted the cube for 7 days and beam only for 28 days. The percentage addition by mass of cement for steel fiber is $1.5 \%$ and percentage addition by mass of coarse aggregate for glass fiber is 1\%. We are going to compare the results of compression test as well as flexural strength to normal concrete through different $(1.5$ and 1) percentages. Final results, the comparison of normal beam to addition of fiber reinforced concrete beam, the maximum flexural strength is found in addition of steel fiber in concrete beam.
\end{abstract}

Keywords-Steel fiber (SF), Glass fiber (GF), One point load, Flexural behaviour, Beams

\section{INTRODUCTION}

\section{A. General}

In reinforced concrete structures, flexural failure is one of the main threats being faced. Many methods were adopted to increase the strength and flexural behaviour of the structure. Since plain concrete possesses very low tensile strength, limited ductility, and little resistance to cracking. Internal micro-cracks are present in the concrete and these micro-cracks are caused due to low tensile strength. By using fibre reinforced concrete the toughness of the structure.

Nowadays, fibres are produced from different materials such as steel, glass, carbon, and synthetic material. Each one of these fibres has its specific benefits. However, steel fibre is

Revised Manuscript Received on October 22, 2019.

R. Chitra, Asistant Professor, Department Of Civil Engineering,,Bharath Institution of Higher Education And Research,TamilNadu, India Email chitraroopauma@gmail.com

S.J.Mohan, Asistant Professor,,Department Of Civil Engineering,,Bharath Institution Of Higher Education And Research,TamilNadu, India .Email: mohansjm@yahoo.com

Thendral Sundararasan, Asistant Professor, Department Of Civil Engineering,,Bharath Institution of Higher Education And Research,TamilNadu, India Email: thendral.cs@gmail.com

Arunya.A, Asistant Professor,,Department Of Civil Engineering,,Bharath Institution Of Higher Education And Research,TamilNadu, India .Email: arunyaaaa@gmail.com the most common one. It has been reported that the first experimental trail to improve concrete characteristics using discontinues steel reinforcing elements, such as nail segment, was done in 1910. However, it was not until 1963 when major experiments were done to improve concrete characteristics using real steel fibres. A typical length of steel fibres ranges from 0.25 to 2.5 in (6 to $64 \mathrm{~mm}$ ), and its diameter ranges from 0.02 to 0.04 in $(0.5$ to $1.0 \mathrm{~mm})$. steel fibres are produced in different form as shown in figure 1.1. This type of fibre is available commercially in tensile strength up to 300ksi (2068 $\mathrm{MPa})$.

Concrete is weak in tension and micro cracks are developed in conventional reinforced concrete. To avoid the propagation of micro cracks in RCC, fibres are added as secondary reinforcement and it also improves the mechanical properties of concrete. The influences of hooked end fibres in conventional RCC will be studied in this project. The beams with fibres and without fibres are to be tested under monotonic loading, to study the behaviour of SFRC beams in the ultimate and post ultimate regions. Now a days natural disaster such as earthquake, wind force etc. plays an important role in the construction industry. So buildings and other construction work should be designed in good manner, which resist higher loads and seismic forces. Ductility and energy absorption capacity are the main requirement of the earthquake resistant structure. Fibre reinforced concrete posses high strength, improved ductility and enhancing energy absorption capacity. So the study on the flexural behaviour of beams.[1]-[5]

\section{B. Concrete}

Concrete is a widely used construction material for various type of a structure due to its durability. As we know concrete is very strong and versatile mouldable construction material. It consists of cement sand and aggregate mixed with water. The cement and water form a paste or gel which coats the sand and aggregate. Concrete is most used material, which required large quantity of fine aggregate. Is there is great demand of aggregates mainly from Civil engineering industry for road and concrete baring construction.

\section{Cement}

A cement is a binder, a substance used for construction that

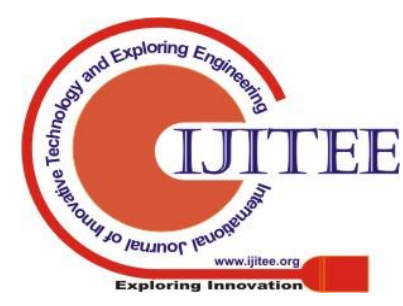


sets, hardens and adheres to other materials, binding them together. Cement is seldom used on its own, but rather to bind sand and gravel (aggregate) together. Cement is used with fine aggregate to produce mortar for masonry, or with sand and gravel aggregates to produce concrete.[6]-[10]

\section{Fine Aggregate} which is generally more angular and has rougher surface texture than river sand particle. The shape and texture of crushed sand particle could lead to improvement in the strength of concrete for to better interlocking between particles. Water reduce sand mineral admixtures can be used to improve workability.

\section{E. Coarse Aggregate}

The Coarse aggregate is passing under $20 \mathrm{~mm}$ and retained in $12.5 \mathrm{~mm}$ sieve. It having specific gravity 2.81 is used. The fineness modulus of coarse aggregate was found to be 2.90.The passing percentage is within the limits as per IS 383-1970.[11]-[15]

\section{F. Steel Fibre.}

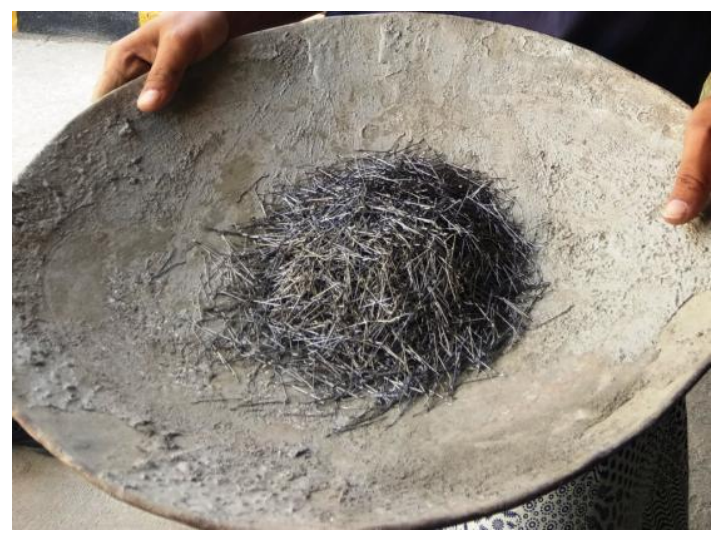

Steel fibres are generally found to have aggregate much greater effect on the flexural strength of SFRC than on either the compressive or tensile strength, with increases of more than $100 \%$ having been reported

\begin{tabular}{|c|c|}
\multicolumn{2}{|c|}{ Tablel Mechanical properties of steel fibres } \\
\hline \multicolumn{2}{|c|}{ Mechanical properties of steel fibres } \\
\hline Diameter & $0.75 \mathrm{MM}$ \\
\hline Length & $60 \mathrm{MM}$ \\
\hline Tensile strength & $1023 \mathrm{MPa}$ \\
\hline $\begin{array}{c}\text { Tolerance for Diameter } \\
\text { and Length }\end{array}$ & $(+) 10 \%$ (As per ASTM) \\
\hline
\end{tabular}

Table 2 Chemical Properties of SF

\begin{tabular}{|c|c|}
\hline $\begin{array}{c}\text { Chemical composition } \\
\text { of Mild steel wire }\end{array}$ & Percentages (\%) \\
\hline $\mathrm{C}$ & 0.074 \\
\hline $\mathrm{d} /$ & 0.36 \\
\hline $\mathrm{Si}$ & 0.065 \\
\hline $\mathrm{P}$ & 0.01 \\
\hline $\mathrm{S}$ & 0.009 \\
\hline
\end{tabular}

Manufactured sand is produced by crushing Rick depositions

\section{G. Glass Fibre}

Glass fibre is a recent introduction in making fibre concrete

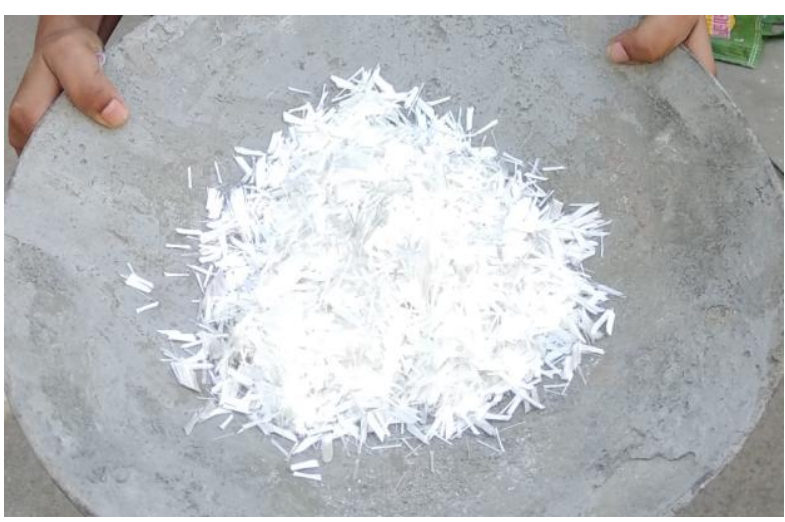

Table 3 Physical Properties of GF

\begin{tabular}{|c|c|}
\hline Property & Glass fiper \\
\hline Specific gravity & 2.42 .8 \\
\hline Bulk density & 2.53 \\
\hline Moisture content(\%) & $\mathbb{N i}$ \\
\hline $\begin{array}{c}\text { Fine particles less } \\
\text { than } 0.075 \mathrm{~mm} \%\end{array}$ & $12-15$ \\
\hline
\end{tabular}

Table 4 Chemical Properties of GF

\begin{tabular}{|c|c|}
\hline Constituent & Glass fiber \\
\hline Silica $\left(\mathrm{SiO}_{2}\right)$ & 72.5 \\
\hline Alumina $\left(\mathrm{Al}_{2} \mathrm{O}_{3}\right)$ & 1.06 \\
\hline Iron Oxide $\left(\mathrm{Fe}_{2} \mathrm{O}_{3}\right)$ & 0.36 \\
\hline Lime $(\mathrm{CgO})$ & 8 \\
\hline Magnesia(M)O & 4.18 \\
\hline Sodium Oxide $\left(\mathrm{Na}_{2} \mathrm{O}\right)$ & 13.1 \\
\hline Potas sium oxide $\left(\mathrm{K}_{2} \mathrm{O}\right)$ & 0.26 \\
\hline Sulphur Trioxide $\left(\mathrm{SO}_{3}\right)$ & 0.18 \\
\hline
\end{tabular}

\section{OBJECTIVE}

$>$ To find the flexural strength of concrete beam at optimum percentage by literature review.

$>$ To compare the flexural behaviour of concrete beam using addition of steel fibres and glass fibres with normal beam in M30 grade concrete. 
$>$ To finds the cracks developed in the concrete beams.

\section{SCOPE}

The scope of this investigation is find out the flexural behaviour of steel fibre in concrete beam thereby the optimum amount of steel and glass fibre that can be used in various applications such as Pavements, Industries floor etc. thus enhance the concrete quality.[17]-[25]

\section{METHODLOGY}

In this experiment we studied the literature review and collected the materials such as Steel fibre, Glass fibre, coarse aggregate, fine aggregate, cement and did a preliminary test like specific gravity, impact test, fineness of cement and considered M30 grade mix design and casted a cube for 7days and beams for 28 days of curing. The cube are tested on compressive strength and the beams are tested on flexural strength to find the cracks pattern.

\section{PRELIMINARY TEST AND MIX DESIGN}

Preliminary test are carried out as per IS Standard to determine the properties of fine aggregate and coarse aggregate. For fine aggregates, test of specific gravity, water C. absorption and gradation are found out and for coarse aggregates, test of specific gravity, Impact value, crushing value are conducted and the results are tabulated in Table

Test on fresh concrete is carried out as per IS Standard to determine the properties of fresh concrete. Slump test is conducted as per IS 1199:1959 to determine the workability of fresh concrete. [26]-[34]

\section{EXPERIMENTAL RESULTS FOR HARDENED CONCRETE}

3D shape form, chamber form and shaft form were utilized to set up the solid examples for the assurance of different quality attributes. Care was taken during throwing and vibrator was utilized for appropriate compaction. Every one of the examples were set up as per Indian Standard Specification IS: 516-1959. Every one of the molds were cleaned and oiled appropriately. These molds were safely fixed to address measurements before throwing. Care was taken that there is no holes left from where there is any probability of spillage out of slurry.

\begin{tabular}{|l|l|l|l|}
\hline & $\begin{array}{l}\text { Ordinary } \\
\text { concrete } \\
\text { (N/mm2) }\end{array}$ & $\begin{array}{l}\text { Concrete } \\
\text { with SF } \\
\text { (N/mm2) }\end{array}$ & $\begin{array}{l}\text { Concrete } \\
\text { with GF } \\
\text { (N/mm2) }\end{array}$ \\
\hline $\begin{array}{l}\text { Compression } \\
\text { tests of } \\
\text { cubes for } 7 \\
\text { days }\end{array}$ & 28.30 & 32.85 & 30.45 \\
\hline $\begin{array}{l}\text { Tensile test } \\
\text { of cylinders } \\
7 \text { days }\end{array}$ & 3.21 & 3.95 & 3.80 \\
\hline
\end{tabular}

\section{A. Reinforcement Details}

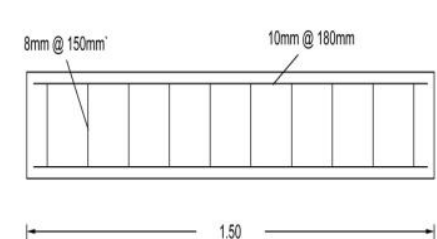

LONGITUDINAL SECTION

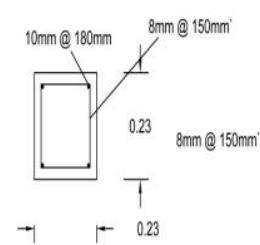

CROSS SECTION
Provide 2 legged stirrups of $8 \mathrm{~mm}$ diameter bar @ 150mm c/c.

\section{B. Casting Of Specimens}

The dimension of the beam specimens to be prepared is $1500 \mathrm{~mm} \times 230 \mathrm{~mm} \times 230 \mathrm{~mm}$ as shown in figure specimens has to be casted for this experiment using M30 grade of concrete. A standard curing will be done for 28 days after casting of specimens.

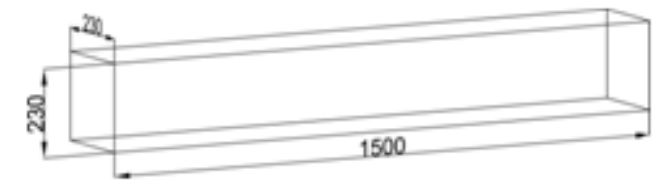

Typical diagram of beam dimension

\section{Binding And Placing Of Reinforcement In The Mould}

Reinforcements used in the specimen consists of 2, $10 \mathrm{~mm}$ dia bars which is provided as the main longitudinal reinforcement and 2,10mm dia bars is used at the top. $8 \mathrm{~mm}$ dia bars is used as stirrups at a spacing of $150 \mathrm{~mm} \mathrm{c/c}$.

The reinforcements are placed inside the mould by giving side and bottom covers respectively. Through oiling of the mould is done before placing the reinforcements. Cover blocks were used to keep the reinforcements in position

\section{Compaction}

Compaction is finished with the assistance of needle vibrator in every one of the examples and care is taken to keep away from removal of the support confine inside the structure work. At that point the outside of the solid is leveled and smoothened by metal trowel and wooden buoy.

\section{E. Curing Of Concrte}

Relieving is done to forestall the loss of water which is basic for the procedure of hydration and consequently for solidifying. It additionally anticipates the introduction of cement to a hot environment and to drying winds which may prompt fast drying out of dampness in the solid and there by subject it to compression worries at a phase when the solid would not be sufficient to opposes at that point. Here clammy relieving is to be finished by splashing water on the jute sacks spread over the outside of the test example. 


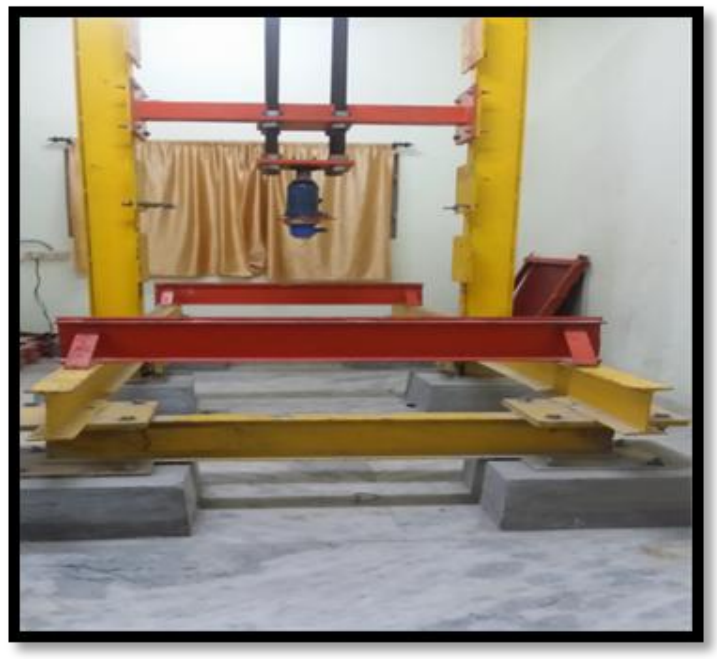

Self-Straining Load Frame and Hydraulic Loading Jack

\section{RESULTS AND DISCUSSION}

\section{A. Load Vs Deflection Of Conventional Beam}

\begin{tabular}{|c|c|}
\hline LOAD (T) & $\begin{array}{c}\text { DEFLECTION } \\
(\mathrm{mm})\end{array}$ \\
\hline 0 & 0 \\
\hline 0.5 & 2.902 \\
\hline 1.0 & 3.689 \\
\hline 1.5 & 3.989 \\
\hline 2.0 & 4.256 \\
\hline 2.5 & 4.464 \\
\hline 3.0 & 5.149 \\
\hline 3.5 & 5.64 \\
\hline 4.0 & 6.211 \\
\hline 4.5 & 7.6 \\
\hline 5.0 & 8.66 \\
\hline 5.29 & 9.06 \\
\hline & \\
\hline
\end{tabular}

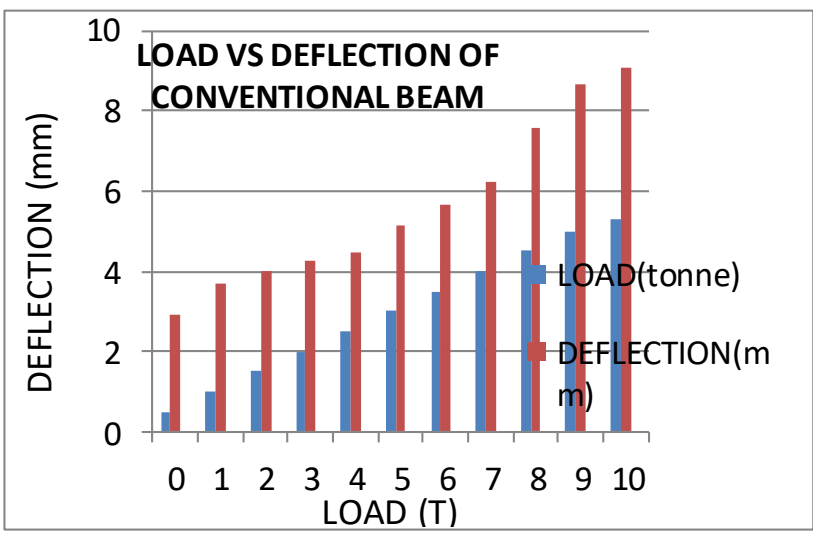

Figure show the load and deflection relationship for beam. An ultimate load of 5.29 tonne was achieved for $1.5 \mathrm{~m}$ span of RC Beam with a maximum deflection of $9.06 \mathrm{~mm}$

\section{B. Load Vs Deflection Curve Using Steel Fibre In Rc} Beam

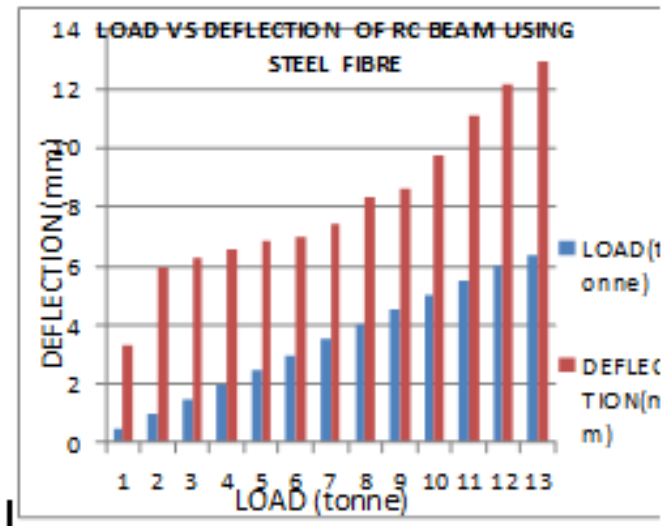

Figure show the load and deflection relationship for beam. An ultimate load of 6.35 tonne was achieved for $1.5 \mathrm{~m}$ Beam span of $\mathrm{RC}$ with a maximum deflection of $12.91 \mathrm{~mm}$

\section{Load Vs Deflection Curve Using Glass Fibre In Rc Beam}

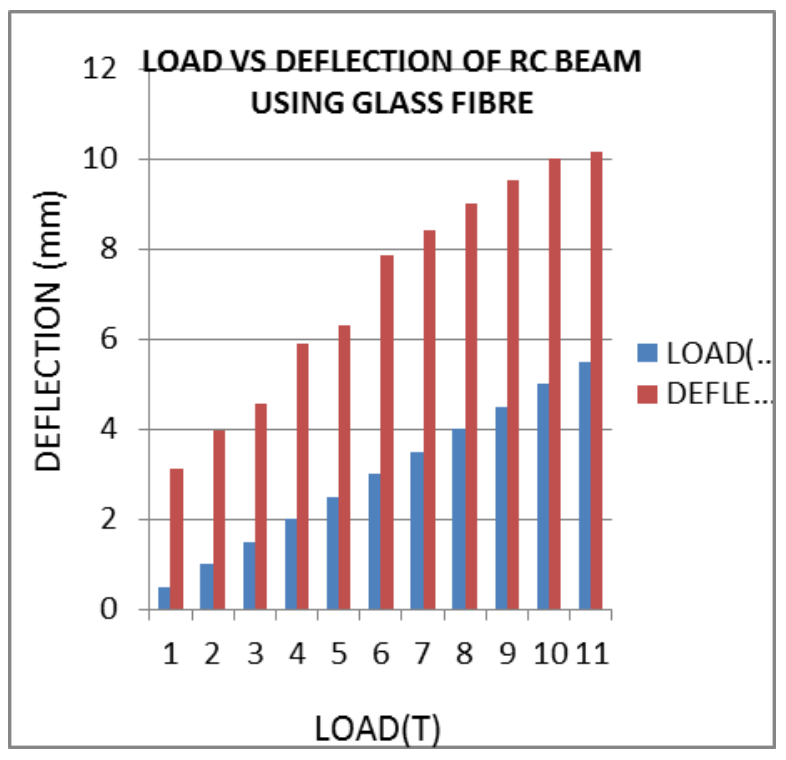

Figure show the load and deflection relationship for beam. An ultimate load of 5.5 tonne was achieved for $1.5 \mathrm{~m}$ span of $\mathrm{RC}$ Beam with a maximum deflection of $10.15 \mathrm{~mm}$

D. Comparision Graph Of Re Beam Using Steel And Glass Fibre

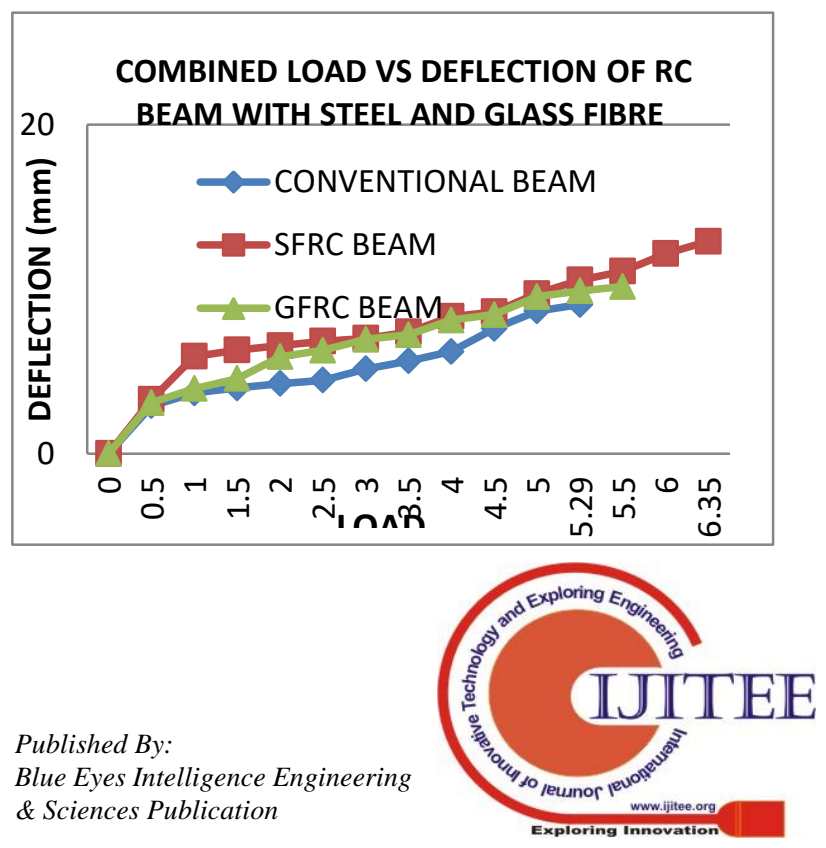




\section{E. Comparision Graph Of Rc Beam Using Steel And} Glass Fibre

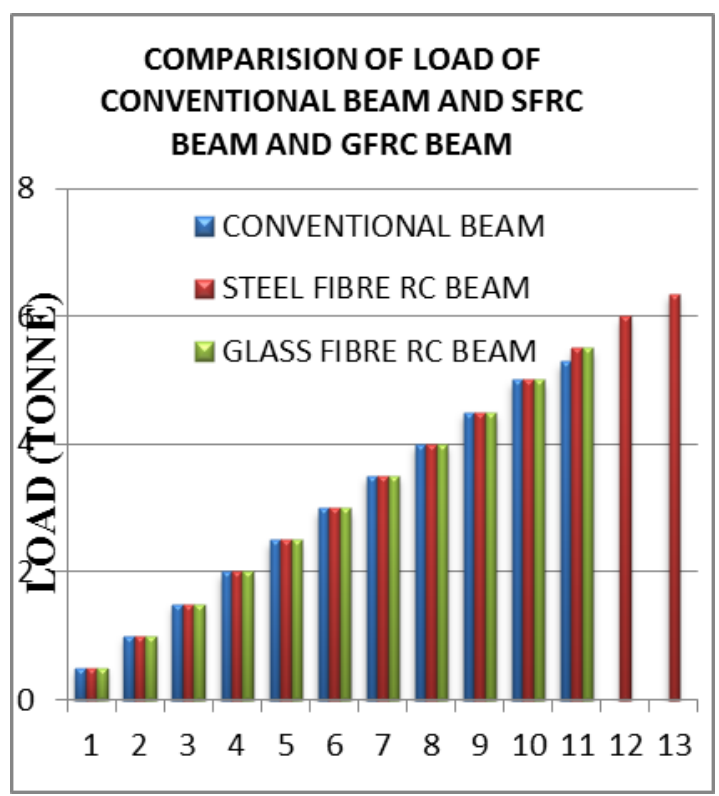

F. Comparision Of Ultimate Load

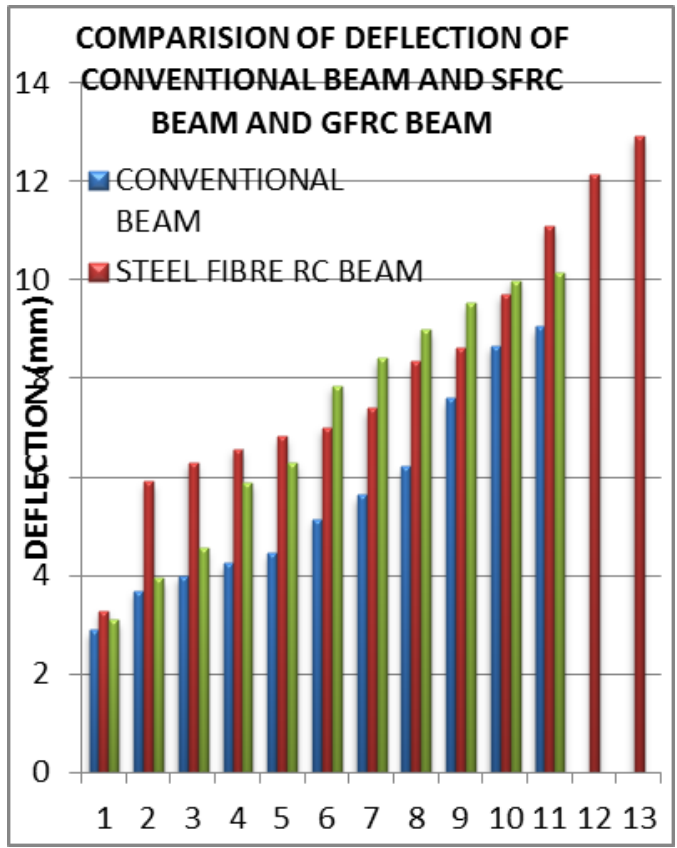

\section{G. Comparision Of Deflection}

Figure show the load and deflection relationship for group I,II and III beams. Group I beam shows an ultimate load of 5.29 tonne was achieved for $1.5 \mathrm{~m}$ span of RC Beam with a maximum deflection of $9.06 \mathrm{~mm}$. Group II beam shows an ultimate load of 6.35 tonne was achieved for $1.5 \mathrm{~m}$ span of RC Beam with a maximum deflection of $12.91 \mathrm{~mm}$. Group III beam shows an ultimate load of 5.5 tonne was achieved for $1.5 \mathrm{~m}$ span of RC Beam with a maximum deflection of $10.15 \mathrm{~mm}$

\section{CONCLUSION}

$>$ An ultimate load of 5.29 tonne was achieved for $1.5 \mathrm{~m}$ span of RC Beam with a maximum deflection of $9.06 \mathrm{~mm}$.

$>$ An ultimate load of 6.35 tonne was achieved for $1.5 \mathrm{~m}$ span of RC Beam with a maximum deflection of $12.91 \mathrm{~mm}$.

$>$ An ultimate load of 5.5 tonne was achieved for $1.5 \mathrm{~m}$ span of RC Beam with a maximum deflection of $10.15 \mathrm{~mm}$.
$>$ Final results, the comparison of normal beam to addition of fiber reinforced concrete beam, the maximum flexural strength is found in addition of steel fiber in concrete beam. $>$ Thereby the optimum amount of steel fibre that can be used in various applications such as Pavements, Industries floor etc. thus enhance the concrete quality.

\section{REFERENCES}

1. Iyappan L., Dayakar P., Identification of landslide prone zone for coonoortalukusing spatial technology, International Journal of Applied Engineering Research,V-9,I-22,PP-5724-5732,Y-2014.

2. Kumar J., Sathish Kumar K., Dayakar P.,Effect of microsilica on high strength concrete, International Journal of Applied Engineering Research,V-9,I-22,PP-5427-5432,Y-2014.

3. Dayakar P., Vijay Ruthrapathi G., Prakesh J., Management of bio-medical waste, International Journal of Applied Engineering Research,V-9,I-22,PP-5518-5526,Y-2014

4. Swaminathan N., Dayakar P., Resource optimization in construction project, International Journal of Applied Engineering Research,V-9,I-22,PP-5546-5551,Y-2014.

5. Venkat Raman K., Dayakar P., Raju K.V.B.,An experimental study on effect of cone diameters in penetration test on sandy soil, International Journal of Civil Engineering and Technology,V-8,I-8,PP-1581-1588,Y-2017.

6. Saritha B., Chockalingam M.P.,Photodradation of malachite green DYE using TIO2/activated carbon composite, International Journal of Civil Engineering and Technology,V-8,I-8,PP-156-163,Y-2017

7. Shendge R.B., Chockalingam M.P., Saritha B., Ambica A.,Swat modelling for sediment yield: A case study of Ujjani reservoir in Maharashtra, India,International Journal of Civil Engineering and Technology,V-9,I-1,PP-245-252,Y-2018

8. Chockalingam M.P., Balamurgan V.,Modernisation of an existing urban road-sector in Chennai, a case study report,International Journal of Civil Engineering and Technology,V-8,I-8,PP-1457-1467,Y-2017

9. Saritha B., Chockalingam M.P.,Adsorption study on removal of basic dye by modified coconut shell adsorbent, International Journal of Civil Engineering and Technology,V-8,I-8,PP-1370-1374,Y-2017

10. Saritha B., Chockalingam M.P.,Adsorptive removal of heavy metal chromium from aqueous medium using modified natural adsorbent,International Journal of Civil Engineering and Technology,V-8,I-8,PP-1382-1387,Y-2017

11. Chockalingam M.P., Palanivelraja S.,Retrospective analysis of a theoretical model used for forecasting future air quality near the north Chennai thermal power plant,International Journal of Civil Engineering and Technology,V-8,I-8,PP-1457-1467,Y-2017

12. Saritha B., Chockalingam M.P.,Photodegradation of methylene blue dye in aqueous medium by $\mathrm{Fe}-\mathrm{AC} / \mathrm{TiO} 2$ Composite,Nature Environment and Pollution Technology,V-17,I-4,PP-1259-1265,Y-2018

13. Shendge R.B., Chockalingam M.P., Kaviya B., Ambica A.,Estimates of potential evapotranspiration rates by three methods in upper Bhima Basin, In Maharashtra, India,International Journal of Civil Engineering and Technology,V-9,I-2,PP-475-480,Y-2018

14. Shendge R.B., Chockalingam M.P.,The soil and water assessment tool for Ujjani Reservoir,International Journal of Mechanical Engineering and Technology,V-9,I-2,PP-354-359,Y-2018

15. Shendge R.B., Chockalingam M.P.,A review on soil and water assessment tool,International Journal of Mechanical Engineering and Technology,V-9,I-2,PP-347-353,Y-2018

16. Sachithanandam P., Meikandaan T.P., Srividya T.,Steel framed multi storey residential building analysis and design,International Journal of Applied Engineering Research,V-9,I-22,PP-5527-5529,Y-2014

17. Meikandaan T.P., Ramachandra Murthy A.,Study of damaged RC beams repaired by bonding of CFRP laminates,International Journal of Civil Engineering and Technology,V-8,I-2,PP-470-486,Y-2017

18. Meikandaan T.P., Ramachandra Murthy A.,Retrofittng of reinforced concrete beams using GFRP overlays,International Journal of Civil 
Engineering and Technology,V-8,I-2,PP-423-439,Y-2017

19. Meikandaan T.P., Ramachandra Murthy A.,Flexural behaviour of RC beam wrapped with GFRP sheets,International Journal of Civil Engineering and Technology,V-8,I-2,PP-452-469,Y-2017

20. Meikandaan T.P., Murthy A.R.,Experimental study on strengthening of rc beams using glass Fiber,International Journal of Civil Engineering and Technology,V-9,I-11,PP-959-965,Y-2018

21. Meikandaan T.P., Hemapriya M.,Use of glass FRP sheets as external flexural reinforcement in RCC Beam,International Journal of Civil Engineering and Technology,V-8,I-8,PP-1485-1501,Y-2017

22. Saraswathy R., Saritha B.,Planning of integrated satellite township at Thirumazhisai,International Journal of Applied Engineering Research,V-9,I-22,PP-5558-5560,Y-2014

23. Saritha B., Ilayaraja K., Eqyaabal Z.,Geo textiles and geo synthetics for soil reinforcement,International Journal of Applied Engineering Research,V-9,I-22,PP-5533-5536,Y-2014

24. Ambica A., Saritha B., Changring G., Singh N B., Rajen M., Salman Md.,Analysis of groundwater quality in and around Tambaram taluk, Kancheepuram district,International Journal of Civil Engineering and Technology,V-8,I-8,PP-1362-1369,Y-2017

25. Arunya A., Sarayu K., Ramachandra Murthy A., Iyer N.R.,Enhancement of durability properties of bioconcrete incorporated with nano silica,International Journal of Civil Engineering and Technology,V-8,I-8,PP-1388-1394,Y-2017

26. Ilayaraja K., Krishnamurthy R.R., Jayaprakash M., Velmurugan P.M., Muthuraj S.,Characterization of the 26 December 2004 tsunami deposits in Andaman Islands (Bay of Bengal, India),Environmental

Earth

Sciences,V-66,I-8,PP-2459-2476,Y-2012

27. Ilayaraja K.,Morphometric parameters of micro watershed in Paravanar sub-basin, Cuddalore District,International Journal of Civil Engineering and Technology,V-8,I-8,PP-1444-1449,Y-2017

28. Ilayaraja K., Singh R.K., Rana N., Chauhan R., Sutradhar N.,Site suitability assessment for residential areas in south Chennai region using remote sensing and GIS techniques,International Journal of Civil Engineering and Technology,V-8,I-8,PP-1468-1475,Y-2017

29. Ilayaraja K., Reza W., Kumar V., Paul S., Chowdhary R.,Estimation of land surface temperature of Chennai metropolitan area using Landsat images,International Journal of Civil Engineering and Technology,V-8,I-8,PP-1450-1456,Y-2017

30. Chitra R.,Experimental study on beam using steel fiber and latex,International Journal of Civil Engineering and Technology,V-8,I-8,PP-1395-1403,Y-2017

31. Chitra R.,Analysis of traffic and management at Kovilambakkam intersection,International Journal of Civil Engineering and Technology,V-8,I-8,PP-1433-1443,Y-2017

32. Aswathy M.,Experimental study on light weight foamed concrete,International Journal of Civil Engineering and Technology,V-8,I-8,PP-1404-1412,Y-2017

33. Aswathy M.,Wastewater treatment using constructed wetland with water lettuce (Eichornia Crasipies),International Journal of Civil Engineering and Technology,V-8,I-8,PP-1413-1421,Y-2017

34. Kiruthiga K., Anandh K.S., Gunasekaran K, Assessment of influencing factors on improving effectiveness and productivity of construction engineers, 2015, International Journal of Applied Engineering Research, V - 10,I -17,p -13849-13854.

\section{AUTHORS PROFILE}

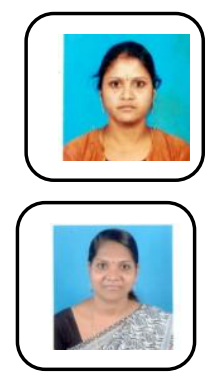

R. Chitra, Asistant Professor, Department Of Civi Engineering,,Bharath Institution of Higher Education And Research,TamilNadu, India

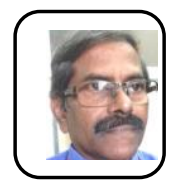

Thendral Sundararasan, Asistant Professor, Department Of Civil Engineering,,Bharath Institution of Higher Education And Research,TamilNadu, India

S.J.Mohan Professor,,Department Of Civil Engineering,,Bharath Institution Of Higher Education And Research,TamilNadu, India

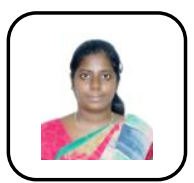

Arunya.A, Asistant Professor,,Department Of Civil Engineering,,Bharath Institution Of Higher Education And Research,TamilNadu, India 